\title{
Physicochemical characterisation of the mature-green Golden apple (Spondias cytherea Sonnerat)
}

\author{
Séverine FrANQUin ${ }^{a, b}$, Odile MARCelin ${ }^{b}$, Guylène AURORE ${ }^{c}$, Max REYNes ${ }^{a}$, Jean-Marc Brillouet ${ }^{a *}$
}

a Centre de Coopération Internationale en Recherche Agronomique pour le Développement (CIRAD), Département FLHOR, TA 50/16, 34398 Montpellier Cedex 5, France

brillouet@cirad.fr

b Groupe A.H. Despointes, Usine Denel, 97132 Gros Morne, France

c Université des AntillesGuyane, Institut Universitaire de Technologie,

Campus de Saint-Claude, 97115 Saint-Claude, France

\section{Physicochemical characterisation of the mature-green Golden apple (Spondias cytherea Sonnerat).}

Abstract - Introduction. Mature-green Golden apples (Spondias cytherea Sonnerat) are used in the French West Indies for the preparation of a nectar. With the aim of improving the fruit processing conditions for a better quality of this beverage, morphological and compositional characteristics of the mature-green fruits were determined. Materials and methods. Maturegreen fruits were harvested in Martinique (French West Indies) and characterised: diameter, length, mass, and colour were determined; $\mathrm{pH}$, titratable acidity, soluble solids, sugars, proteins, starch, fibre, vitamin $\mathrm{C}$, phenols and green pigments were measured. Results and discussion. Average fruit length, diameter and weight were $71 \mathrm{~mm}, 54 \mathrm{~mm}$ and $116.4 \mathrm{~g}$, respectively. With a low pH (2.6) and a high titratable acidity ( $1.3 \mathrm{~g}$ citric acid Eq $100 \mathrm{~g}^{-1}$ fresh material), maturegreen Golden apple is an acidic fruit comparable to the lemon. The fruit is rich in vitamin $\mathrm{C}$ $\left(52.0 \mathrm{mg} \cdot 100 \mathrm{~g}^{-1}\right)$, phenols (349.5 mg gallic acid Eq $100 \mathrm{~g}^{-1}$ ) and starch $\left(7.1 \mathrm{~g} \cdot 100 \mathrm{~g}^{-1}\right)$. The pale green colour of the pulp is due to pheophytins a and b. Conclusion. Our study provided a detailed analysis of mature-green Golden apples, which will be taken into account for the improvement of nectar processing conditions.

France / Guadeloupe / Spondias cytberea / Anacardiaceae / fruits / chemical composition / ascorbic acid / starch / phenols / chlorophylls / phaeophytins
${ }^{*}$ Correspondence and reprints

Received 23 November 2004 Accepted 15 March 2005

Fruits, 2005, vol. 60, p. 203-210 (C) $2005 \mathrm{Cirad} / \mathrm{EDP}$ Sciences All rights reserved

DOI: $10.1051 /$ fruits:2005027

RESUMEN ESPAÑOL, p. 210

\section{Caractérisation physico-chimique de la prune de Cythère mature verte (Spondias cytherea Sonnerat).}

Résumé - Introduction. La prune de Cythère verte mature (Spondias cytherea Sonnerat) est utilisée aux Antilles françaises pour la préparation d'un nectar. Les caractéristiques morphologiques et la composition de ce fruit ont été déterminées avec l'objectif d'améliorer à terme ses conditions de transformation pour une meilleure qualité de la boisson obtenue. Matériel et méthodes. Des fruits verts matures ont été récoltés en Martinique (Antilles françaises) et caractérisés : le diamètre, la longueur, le poids et la couleur ont été déterminés ; le pH, l'acidité titrable, les solides solubles, les sucres, les protéines, l'amidon, les fibres, la vitamine C, les phénols et les pigments verts ont été mesurés. Résultats et discussion. Les longueur, diamètre et poid moyen des fruits sont respectivement de $71 \mathrm{~mm}, 54 \mathrm{~mm}$ et $116,4 \mathrm{~g}$. Avec un $\mathrm{pH}$ faible $(2,6)$ et une acidité titrable élevée $\left(1,3 \mathrm{~g} \mathrm{Eq}\right.$ acide citrique $100 \mathrm{~g}^{-1}$ matière frâiche), la prune de Cythère verte est un fruit acide comparable au citron. Le fruit est riche en vitamine $\mathrm{C}$ $\left(52,0 \mathrm{mg} \cdot 100 \mathrm{~g}^{-1}\right)$, en phénols $\left(349,5 \mathrm{mg}\right.$ Eq acide gallique $\left.\cdot 100 \mathrm{~g}^{-1}\right)$ et en amidon $\left(7,1 \mathrm{~g} \cdot 100 \mathrm{~g}^{-1}\right)$. La couleur vert pâle de la pulpe industrielle est due aux phéophytines a et b. Conclusion. Notre étude a fourni une analyse détaillée de prunes de Cythère vertes matures qui sera prise en compte pour améliorer les conditions de leur transformation en nectar.

France / Guadeloupe / Spondias cytberea / Anacardiaceae / fruits / composition chimique / acide ascorbique / amidon / phénol / chlorophylle / phéophytine 


\section{Introduction}

The Golden apple (Spondias cytherea Sonnerat or Spondias dulcis Forst.), also called Otaheite apple, a native of Polynesia, belongs to the Anacardiaceae family which includes the mango, Mangifera indica L., and the cashew, Anacardium occidentale L. [1]. It is mainly cultivated in the Caribbean region, Asia, Central America, South America and, in a lesser proportion, in Africa. This wide distribution of the fruit is reflected by a multitude of vernacular names according to the considered area: e.g., "pomme-Cythère" in Trinidad and Tobago, St. Lucia and Dominica, "prune de Cythère" in the French West Indies, "june plum" in Jamaica and Grenada, "ciruela dulce" in Cuba, "càja-manga" in Brazil, "ambarella" in Florida and "jobo" in India [2, 3].

The fruit is an ovoid drupe with a spiny stone (figure 1). Two forms of Golden apples are encountered: the large type (diameter 5$6 \mathrm{~cm}$, length 9-10 cm, average weight $200 \mathrm{~g}$ ), and the miniature type (diameter $4-5 \mathrm{~cm}$, length 5-6 cm, average weight $65 \mathrm{~g}$ ) [4] The growth and development to maturity of the miniature Golden apple was studied by Graham et al. [4], showing that the harvest maturity or the mature-green stage of development is attained after 19 to 21 weeks after fruit-set. From this point to the fully ripe stage, the skin turns progressively from green to bright yellow to orange, and the flesh from whitish to yellow [2].
The ripe fruits are used to make jams, preserves, juices [5], and sparkling beverages [6]. The mature-green fruits are also used for pickling and relish dishes. Geographically more restricted is the use of mature-green fruits to elaborate a drink much appreciated by the consumers of the French West Indies (Martinique and Guadeloupe) and Grenada due to its slight acidity and astringency, and its olive green colour provided by the green pigments entrapped in the outer layers of the fruit (figure 1). Briefly, fruits are washed, crushed, pressed, and the crude pulpy juice is sieved prior to conditioning as a nectar (addition of sucrose and water), pasteurisation, and bottling (François-Haugrin, pers. commun., 2003). However, this drink elaborated with mature-green Golden apples contains starch which alters the visual appearance of the drink since, on one hand, a white sediment could form in storage on the container bottom, and on the other hand, the whiteness provided by starch makes the olive green colour paler; moreover, pasteurisation of the drink partially destroys the olive green colour of the nectar. Consequently, restoring of this characteristic colour is achieved by adding a chlorophyll extract from corn leaves (François-Haugrin, pers. commun., 2003). Moreover, as pasteurisation is not well controlled, this drink has a short shelf life that limits its export to non-ethnic markets.

In order to improve the quality of the drink, it has been suggested to use commercial
Figure 1.

Structure of the mature-green Golden apple. (A) skin colour reconstituted from measured $\left(L^{*}, a^{*}, b^{*}\right)$ parameters (table $\left.I\right)$ (see colour picture on Fruits' website).

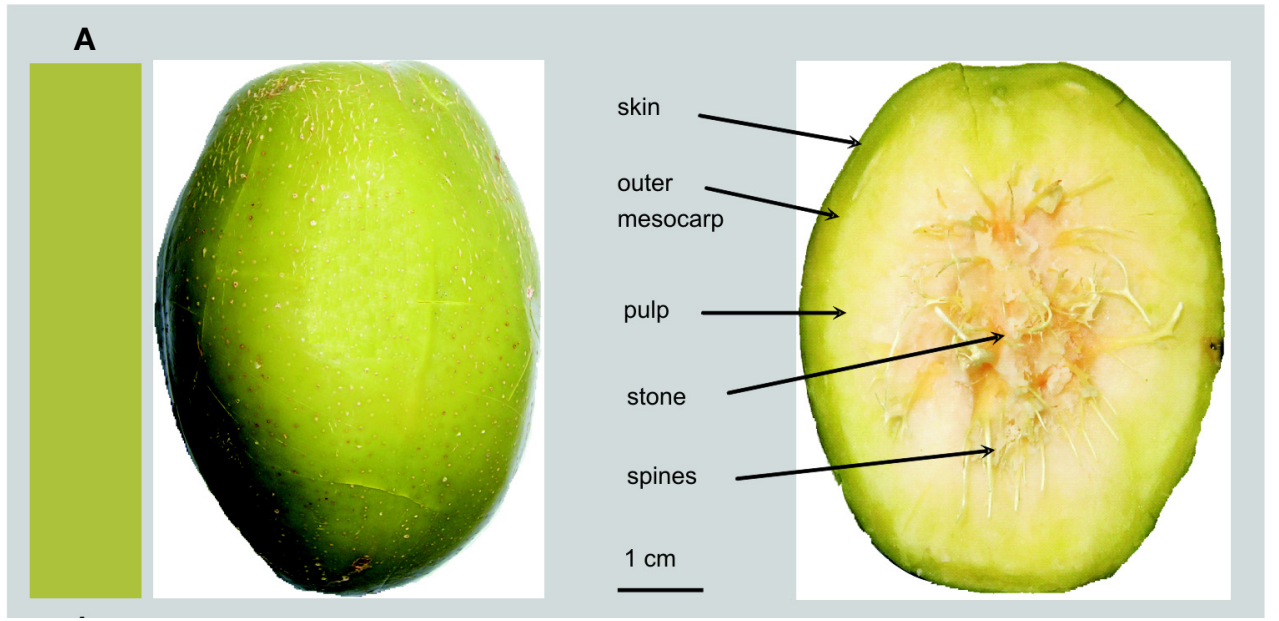


enzymes which would degrade both cellwalls and starch to, on one hand, increase the juice extraction yield, and on the other hand, get rid of starch, a source of visual defect. A previous study showed that a commercial amyloglucosidase allowed total degradation of the mature-green Golden apple starch into glucose, thus increasing the total soluble solids [7].

Thus, the objective of our study was to measure the physical and physicochemical characteristics of a population of maturegreen Golden apples representative of fruits used in the French West Indies for the nectar elaboration. Based on these results, enzymatic treatments could thereby be designed.

\section{Materials and methods}

\subsection{Plant material}

One hundred and forty-three (143) sound mature-green to turning-green Golden apples were harvested on several trees in domestic orchards in Martinique (French West Indies), cleaned, and washed. Fruit description is presented in figure 1. Amongst them, 79 maturegreen Golden apples were sorted out by visual appreciation of the skin colour; then 15 fruits were randomly chosen and 5 batches of 3 fruit each were created $\left(G_{1}\right.$ to $\left.G_{5}\right)$. Fruits were frozen $\left(-20^{\circ} \mathrm{C}\right)$ before analysis.

\subsection{Physical methods of analysis}

The physical analyses were performed on whole fresh fruits. Size $(\mathrm{mm})$ was measured with a calliper (Mitutoyo Digimatic model CD15B). Mass (g) was measured on each fruit with a Sartorius balance (precision $0.1 \mathrm{~g}$ ). Colour of the skin $\left(L^{*}, a^{*}, b^{*}\right)$ was determined using a tristimulus Minolta CR-200 chromameter (Minolta Corp., Ramsey, N.J., USA); the true colour was reconstituted taking into account measured $\left(L^{*}, a^{*}, b^{*}\right)$ values using the software EasyRGB-PC Ver. 1.20 [8] (figure 1).

\subsection{Physicochemical methods of analysis}

Fruits were stoned, cut into pieces, freezedried, then pulverised in liquid nitrogen with a Dangoumeau 300 ball mill (Prolabo, Paris, France) for 5 min (top impact frequency). Water content was thus deduced by the difference between fresh and freezedried matters. Total soluble solids, $\mathrm{pH}$ and titratable acidity were measured after reconstituting the fresh initial flesh by addition of an appropriate amount of distilled water. All data were expressed on a fresh weight basis.

A pH meter (pH-Vision 6071, Jenco Elec. Ltd, Taiwan) was used for measuring $\mathrm{pH}$. Total soluble solids ( ${ }^{\circ}$ Brix) were measured at room temperature on centrifuged juice using an Abbe refractometer with a measuring range of $0-30{ }^{\circ}$ Brix [9]. Titratable acidity (g citric acid Eq·100 $\mathrm{g}^{-1}$ ) was estimated by titration with a $0.1 \mathrm{M} \mathrm{NaOH}$ up to $\mathrm{pH} 8.1$ using phenolphthalein as indicator [9]. Proteins $(\mathrm{N} \times 6.25)$ were determined by the Kjeldahl procedure [10]. Sugars and organic acids were simultaneously determined by HPLC [11] using a cation exchange ION-300 column $(300 \mathrm{~mm} \times 7.8 \mathrm{~mm}$ i.d., Mandel Scientific Co., Rockwood, Canada); sugars and organic acids were eluted at $0.4 \mathrm{~mL} \cdot \mathrm{min}^{-1}$ with $0.0065 \mathrm{~N} \mathrm{H}_{2} \mathrm{SO}_{4}$ at $25^{\circ} \mathrm{C}$, and monitored with a differential refractive index detector (model R410; Waters Associates, Milford, USA). Starch was measured by the UVmethod [12] with correction for endogenous glucose. The fibre constituents (cellulose, hemicelluloses and lignin) were determined by the method of Van Soest and Roberston [13]. Ashes were obtained by heating samples at $100{ }^{\circ} \mathrm{C}(12 \mathrm{~h})$, then $525^{\circ} \mathrm{C}(12 \mathrm{~h})$ [9]. Vitamin C was measured by the 2,6-dichloroindophenol method [14].

\subsection{Determination of phenols}

Phenols were extracted from freeze-dried powder (100 mg) by stirring in 70\% acetone $(10 \mathrm{~mL})$; after $10 \mathrm{~min}$, the slurry was homogenised with an Ultra Turrax and left under stirring for an additional $3 \mathrm{~min}$. The slurry was then filtered on a Whatman filter paper (No. 1), and the filtrate was tested for phenols and interfering substances, e.g., ascorbic acid, by the Folin-Ciocalteu reagent [15]. The actual phenol content was expressed as mg gallic acid Eq $100 \mathrm{~g}^{-1}$ fresh material after correction for vitamin $\mathrm{C}$. 


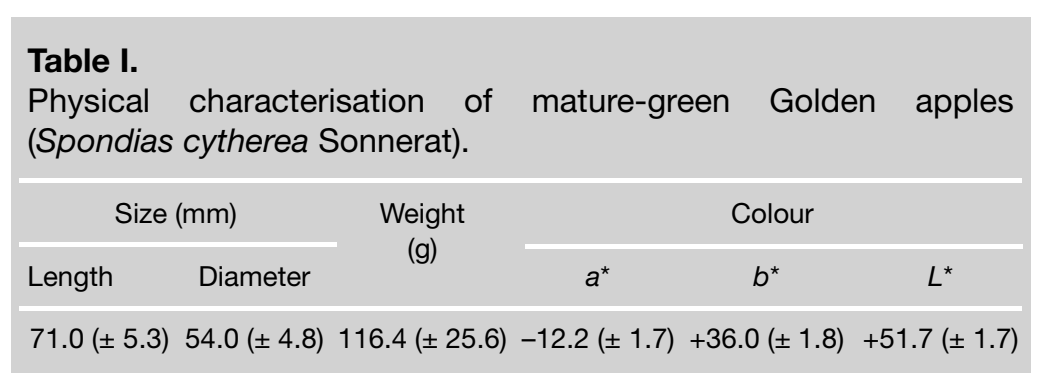

\subsection{Qualitative analysis of green pigments}

Fresh fruit outer layers (i.e., skin and outer mesocarp; 2-3 mm thickness) were obtained with a scalpel, pulverised in liquid nitrogen with a Dangoumeau 300 ball mill for 2 min (top impact frequency), and the pigments were extracted by stirring a powder aliquot $(1 \mathrm{~g})$ in distilled water $(25 \mathrm{~mL})$ with diethyl ether $(60 \mathrm{~mL})$ containing $0.01 \% 2,6$ diterbutyl $p$-cresol for $10 \mathrm{~min}$. The organic phase was recovered and the aqueous phase reextracted twice with ether. The extracts were pooled and, after filtration onto a porous glass crucible (porosity No. 4), brought to dryness under vacuum; the residue was dissolved in diethyl ether $(5 \mathrm{~mL})$. Pigments were separated by HPLC using an Agilent system (1100 series) including a quaternary pump, a manual Rheodyne $7525 \mathrm{i}$ injector, an automated gradient controller and a diode array detector; detection wavelengths were (410, 434, 642 and 663) $\mathrm{nm}$. The column was a reverse phase Lichrospher RP-18 (Merck, Darmstadt, Germany) [(250 × 4.6) $\mathrm{mm}$ i.d., $5 \mu \mathrm{m}$ packing] protected with a guard column of the same material. Flow rate was $1 \mathrm{~mL} \cdot \mathrm{min}^{-1}$ and injected volume was $20 \mu \mathrm{L}$. Three solvents were used: acetonitrile (A), $n$-hexane/dichloromethane 1:1 (B), and methanol / distilled water 9:1 (C) [16]; the elution program was: from $100 \%(\mathrm{C})$ at $0 \mathrm{~min}$ linearly to $45 \%$ (C), $40 \%$ (A) and $15 \%$ (B) at 18 min; linearly to $80 \%$ (A), 15\% (B) and 5\% (C) at $28 \mathrm{~min}$.

\section{Results and discussion}

\subsection{Physical characterisation of the fruits}

The fruit of a mature-green Golden apple is an ovoid green drupe with average length of $\sim 70 \mathrm{~mm}$, diameter of $\sim 55 \mathrm{~mm}$, and weight of $\sim 115 \mathrm{~g}$ (table I). These values agree with previously published morphological characteristics $[2,7]$, but are smaller than values given by Graham et al. [4] for large Golden apples. Its longitudinal section (figure 1) shows a green outer mesocarp (thickness 2$3 \mathrm{~mm}$ ) clearly separated from whitish central and inner mesocarps (pulp) embedding a hard-to-remove spiny stone.

Objective colour measurement $\left(L^{*}, a^{*}, b^{*}\right)$ indicated that fruit skin was green (negative $a^{*}$ value) and yellow (positive $b^{*}$ value). Our $\left(L^{*}, a^{*}, b^{*}\right)$ values agree well with previously published data for miniature mature-green Golden apples (19-21 weeks after fruit-set) [4]. Reconstitution of the true fruit colour [9] (figure 1) agreed with its actual colour. Thus, from a technological point of view, nectars from mature-green Golden apples will exhibit a pale olive green colour, balance between whitish and green, and colour intensity depending, respectively, on the relative proportions and amounts of pulp and outer mesocarp passing the sieving step and found ultimately in the beverage.

\subsection{Physicochemical characterisation of the fruits}

The fruit contents (table II) in total soluble solids $\left(10 \mathrm{~g} \cdot 100 \mathrm{~g}^{-1}\right)$ were higher than those reported by Graham et al. [4] for maturegreen Golden apples at 19-21 weeks after fruit-set $\left(7.5 \mathrm{~g} \cdot 100 \mathrm{~g}^{-1}\right)$. Sugars were mainly sucrose, fructose and glucose. Due to its mature-green status, the fruit flesh has a low $\mathrm{pH}$ comparable to a lime or a lemon juice [17]. The mature-green Golden apples show a high titratable acidity (1.3 g citric acid $\mathrm{Eq} \cdot 100 \mathrm{~g}^{-1}$ ), a value far higher than those given by Graham et al. [4] for miniature mature-green Golden apples at 19-21 weeks after fruit-set $\left(\sim 0.7 \mathrm{~g}\right.$ citric acid Eq·100 g $\left.{ }^{-1}\right)$. Contrary to previously published data [2] which placed malic acid as the most represented organic acid ( $278 \mathrm{mg} \cdot 100 \mathrm{~g}^{-1}$ ) [citric acid being found at $54 \mathrm{mg} \cdot 100 \mathrm{~g}^{-1}$ ], in our study, citric acid is the major organic acid (900 mg $\cdot 100 \mathrm{~g}^{-1}$ ), accounting for $\sim 80 \%$ of the anions present. Malic acid is also present at a level $\left(200 \mathrm{mg} \cdot 100 \mathrm{~g}^{-1}\right)$ resembling the value presented by Daulmerie [2]. 


\begin{tabular}{|c|c|c|c|c|c|c|c|c|c|c|c|c|}
\hline $\mathrm{pH}$ & $\begin{array}{r}\text { Total } \\
(\mathrm{g} \cdot 100\end{array}$ & $\begin{array}{l}\text { solids } \\
\left.\mathrm{g}^{-1} \mathrm{fm}\right)\end{array}$ & $\begin{array}{r}\text { Total s } \\
\text { so } \\
\left({ }^{\circ} \mathrm{B}\right.\end{array}$ & $\begin{array}{l}\text { soluble } \\
\text { lids } \\
\text { Brix) }\end{array}$ & $\begin{array}{r}\text { Suc } \\
(\mathrm{g} \cdot 100\end{array}$ & $\begin{array}{l}\text { rose } \\
\left.g^{-1} f m\right)\end{array}$ & $\begin{array}{l}\text { Fructose } \\
\left(\mathrm{g} \cdot 100 \mathrm{~g}^{-1} \mathrm{fm}\right)\end{array}$ & $\begin{array}{c}\text { Glucose } \\
\left(\mathrm{g} \cdot 100 \mathrm{~g}^{-1} \mathrm{fm}\right)\end{array}$ & $\begin{array}{l}\text { Titratable acidity } \\
\text { ( } \mathrm{g} \text { citric acid } \\
\left.\text { Eq } 100 \mathrm{~g}^{-1} \mathrm{fm}\right)\end{array}$ & $\begin{array}{l}\text { Citric acid } \\
\left(\mathrm{g} \cdot 100 \mathrm{~g}^{-1} \mathrm{fm}\right)\end{array}$ & $\begin{array}{c}\text { Malic acid } \\
\left(\mathrm{g} \cdot 100 \mathrm{~g}^{-1} \mathrm{fm}\right)\end{array}$ & $\begin{array}{c}\text { Oxalic acid } \\
\left(\mathrm{g} \cdot 100 \mathrm{~g}^{-1} \mathrm{fm}\right)\end{array}$ \\
\hline $\begin{array}{l}2.6 \\
( \pm 0.04)\end{array}$ & 20.4 & $( \pm 1.8)$ & 10.0 & $( \pm 0.1)$ & $3.1=$ & $\pm 0.3)$ & $1.5( \pm 0.2)$ & $1.2( \pm 0.2)$ & $1.3( \pm 0.03)$ & $0.9( \pm 0.1)$ & $0.2( \pm 0.02)$ & $0.03( \pm 0.01)$ \\
\hline \multicolumn{2}{|c|}{$\begin{array}{l}\text { Proteins } \\
\left(\mathrm{g} \cdot 100 \mathrm{~g}^{-1} \mathrm{fm}\right)\end{array}$} & \multicolumn{2}{|c|}{$\begin{array}{c}\text { Starch } \\
\left(\mathrm{g} \cdot 100 \mathrm{~g}^{-1} \mathrm{fm}\right)\end{array}$} & \multicolumn{2}{|c|}{$\begin{array}{l}\text { Cellulose } \\
\left(\mathrm{g} \cdot 100 \mathrm{~g}^{-1} \mathrm{fm}\right)\end{array}$} & \multicolumn{2}{|c|}{$\begin{array}{l}\text { Hemicelluloses } \\
\left(\mathrm{g} \cdot 100 \mathrm{~g}^{-1} \mathrm{fm}\right)\end{array}$} & $\begin{array}{l}\stackrel{\text { Lignin }}{\left.\mathrm{g} \cdot 100 \mathrm{~g}^{-1} \mathrm{fm}\right)}(\mathrm{n}\end{array}$ & $\begin{array}{l}\text { Vitamin C } \\
\left.\mathrm{mg} \cdot 100 \mathrm{~g}^{-1} \mathrm{fm}\right) \quad(\mathrm{m}\end{array}$ & \multicolumn{2}{|c|}{$\begin{array}{l}\text { Phenolic compounds } \\
\left.\text { (mg gallic acid Eq } 100 \mathrm{~g}^{-1} \mathrm{fm}\right)\end{array}$} & $\begin{array}{c}\text { Ashes } \\
\left(\mathrm{g} \cdot 100 \mathrm{~g}^{-1} \mathrm{fm}\right)\end{array}$ \\
\hline \multicolumn{2}{|c|}{$0.8( \pm 0.1)$} & \multicolumn{2}{|c|}{$7.1( \pm 0.5)$} & \multicolumn{2}{|c|}{$1.1( \pm 0.1)$} & \multicolumn{2}{|c|}{$0.8( \pm 0.2)$} & $0.5( \pm 0.1)$ & $52.0( \pm 4.9)$ & \multicolumn{2}{|c|}{$349.5( \pm 52.3)$} & $0.5( \pm 0.06)$ \\
\hline
\end{tabular}

Starch was present at a significant level $\left(7.1 \mathrm{~g} \cdot 100 \mathrm{~g}^{-1}\right)$, a value higher than that reported for miniature mature-green Golden apples (19-21 weeks after fruit-set; $\sim 4.5 \mathrm{~g} \cdot 100 \mathrm{~g}^{-1}$ ) [4]. Thus, in the industrial process, after heat treatment of fruits or juices to gelatinise starch, full enzymatic hydrolysis of starch into glucose by a commercial amyloglucosidase would theoretically increase the ${ }^{\circ}$ Brix by 7 units. Proteins $\left(0.8 \mathrm{~g} \cdot 100 \mathrm{~g}^{-1}\right)$ and fibre constituents (sum of cellulose, hemicelluloses and lignin $=$ $2.4 \cdot 100 \mathrm{~g}^{-1}$ ) were found in the range of values reported by Persad [3].

The mature-green Golden apple is as rich in vitamin $C\left(52 \mathrm{mg} \cdot 100 \mathrm{~g}^{-1}\right)$ as the sweet orange Citrus sinensis L. (on average $\sim 50 \mathrm{mg} \cdot 100 \mathrm{~g}^{-1}$ ) [17]. Our average value is not in agreement with data reported by Graham et al. [4] for miniature mature-green Golden apples (19-21 weeks after fruit-set; $10-14 \mathrm{mg} \cdot 100 \mathrm{~g}^{-1}$ ), and are closer to those reported by Daulmerie [2] and Persad [3] (36-42 mg $100 \mathrm{~g}^{-1}$ ). However, the vitamin C content varies with the harvest time and can decrease during the technological process applied to the fruit (e.g., oxidation during the pulp defrosting, degradation due to the pasteurisation). Thus, it is imperative to define a precise harvest stage and to estimate the incidence of the technological treatments on vitamin $C$ present in the Golden apple before using it as a selling argument for the marketable product (antioxidant).
These mature-green Golden apples show a high phenol content $(\sim 350 \mathrm{mg}$ gallic acid $\mathrm{Eq} \cdot 100 \mathrm{~g}^{-1}$ ), a level higher than those known to be rich in these substances [18], e.g., apples and red grapes. Our value is in full disagreement with previously published ones (green fruits; $\sim 4 \mathrm{mg}$ gallic acid $\mathrm{Eq} \cdot 100 \mathrm{~g}^{-1}$ of pulp) [2]. It is worth mentioning that Corthout et al. [19] reported the presence of antiviral phenolic caffeoyl esters in a related species, Spondias mombin $\mathrm{L}$.

\subsection{Green pigments of Golden apple}

Since the pale olive green colour of Golden apple nectars is of prime importance to the consumers, the green pigments located in the outer layers of the fruit (figure 1) were extracted by diethyl ether and separated by HPLC, giving a typical chromatogram of a pigment extract (figure 2). Six peaks were consistently observed: two of them were carotenoids [peak No. 1, $\left(\lambda_{\max }=423,446\right.$, $472 \mathrm{~nm})$; peak No. $6\left(\lambda_{\max }=435,452\right.$, $480 \mathrm{~nm}$ )]; four peaks were chlorophylls and chlorophyll-derived pigments (peaks No. 2 to 5). Analysis of spectra revealed that peaks No. 2 and 3 were chlorophyll b $\left(\lambda_{\max }=313\right.$, $343,436,464,550,600,649 \mathrm{~nm})$ and chlorophyll a $\left(\lambda_{\max }=336,384,414,431,580\right.$, 616, $664 \mathrm{~nm})$, respectively [16, 20, 21]; they were present in minute amounts. The largely dominant peaks No. 4 and No. 5 were identified as pheophytin $\mathrm{b}\left(\lambda_{\max }=330,372,416\right.$, 


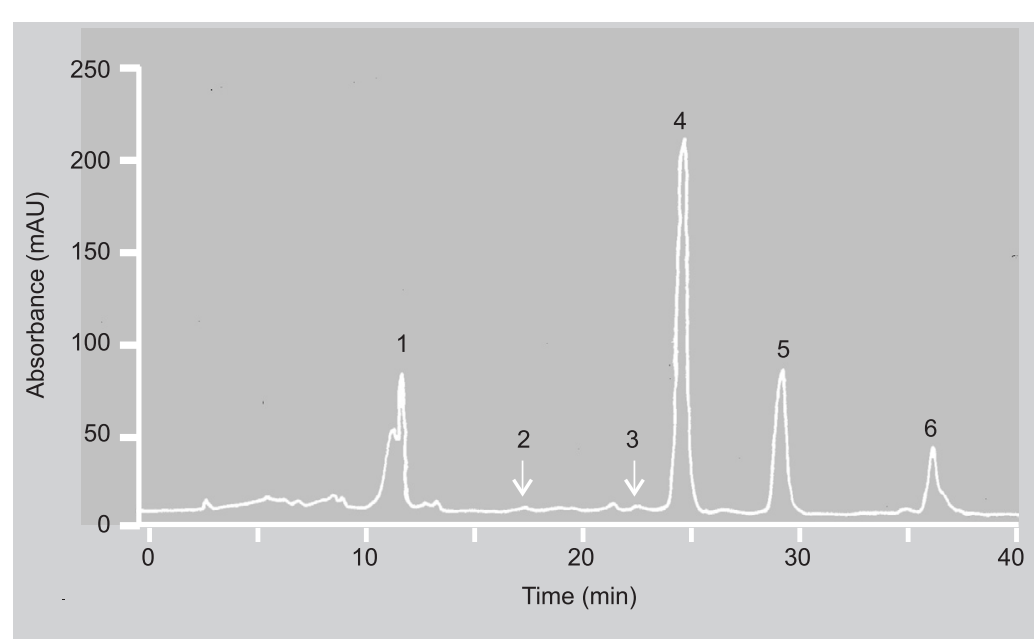

Figure 2.

Reversed phase HPLC separation of the pigments isolated with diethyl ether from mature-green Golden apples. The analytical wavelength is $434 \mathrm{~nm}$ and the injection volume $20 \mu \mathrm{L}$.

\section{Figure 3.}

Influence of $\mathrm{pH}$ on the distribution of green pigments. Absorbance was measured at $654 \mathrm{~nm}$ for chlorophyll b and pheophytin $b$ and at $664 \mathrm{~nm}$ for chlorophyll a and pheophytin a.

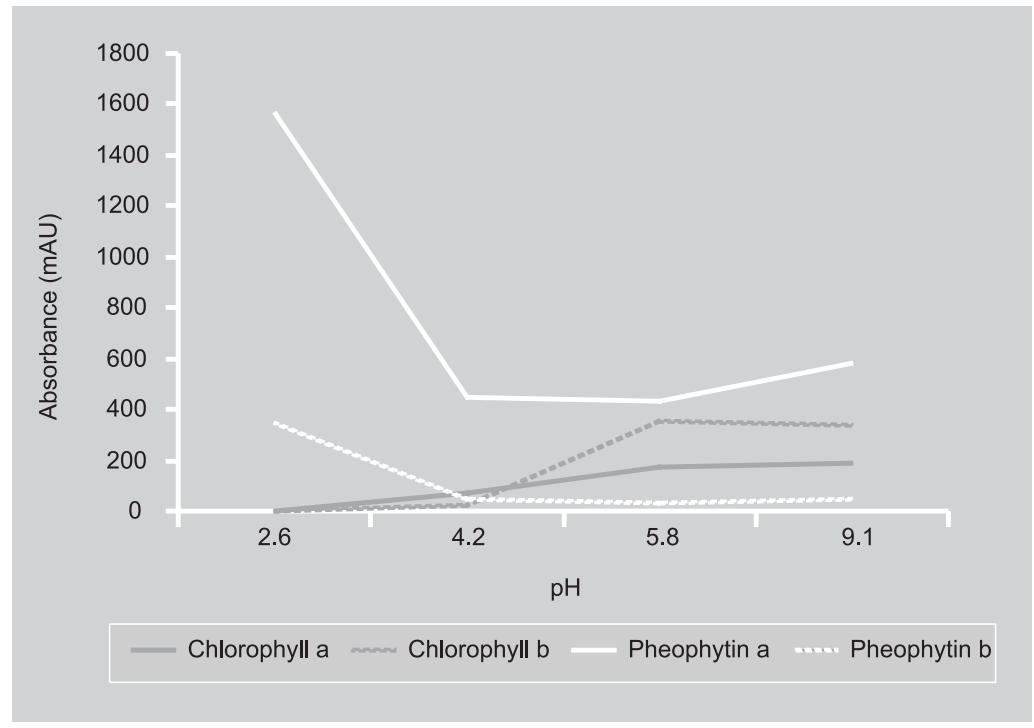

was expected. Confirmation of this result was obtained by spreading various amounts of powdered sodium carbonate onto aliquots of outer layer pieces prior to ball-milling to achieve instant $\mathrm{pH}$ adjustment (from pH 2.6 to 9.1) during ball-milling (figure 3). Clearly, while in the native pulp ( $\mathrm{pH}$ 2.6), pheophytins $\mathrm{a}$ and $\mathrm{b}$ were almost exclusively present, their levels decreased drastically at $\mathrm{pH} 4.2$, then remained constant up to $\mathrm{pH}$ 9.1; on the other hand, chlorophylls $\mathrm{a}$ and $\mathrm{b}$ were regenerated at $\mathrm{pH} 5.8$, then remained stable. Due to the spectral characteristics of pheophytins compared with chlorophylls, this could explain why the acid pulpy juice obtained from maturegreen Golden apple is olive green rather than bright green [24]. This technique will be used in the near future to estimate the capacity of enzymes in the industrial process to improve the pale olive green colour of the nectars.

\section{Conclusion}

A population of mature-green Golden apples (Spondias cytherea Sonnerat), representative of the fruits used in the French West Indies for the elaboration of a nectar, was analysed for its physical and physicochemical characteristics. Fruits exhibited a low $\mathrm{pH}$, a high titratable acidity with citric acid as the dominant anion, and a fairly high content in starch. Moreover, due to a high level in phenols, and a fair content in vitamin C, these fruits are a good source of antioxidants. The green pigments found in outer layers of mature-green Golden apples are pheophytins generated from chlorophylls by the high acidity of the fruits.

\section{Acknowledgements}

We thank A. Desgrottes (Antilles Glace Co., Martinique, France) for providing maturegreen Golden apples. Thanks are due to the French Ministère Délégué à l'Enseignement Supérieur et à la Recherche, the Alain Despointes Group and the Région Martinique for their financial support. 


\section{References}

[1] Purseglove J.W., Anacardiaceae, in: Purseglove J.W. (Ed.), Tropical crops dicotyledons, Vols. 1 and 2, Longman, Group Ltd., London, UK, 1974, pp. 18-32.

[2] Daulmerie S., Investigations on Golden apple (Spondias cytherea) production with particular reference to post-harvest technology and processing, IICA Off. Trinidad \& Tobago and Minist. Aff. Étrang. (France), Fonds Interminist. Caraïbes-Guyanes, Portof-Spain, Trinidad and Tobago, 1994, 112 p.

[3] Persad C., Golden apple, Spondias cytherea Sonn., tree, Trop. Fruits Newsl. 23 (1997) 11-13.

[4] Graham O.S., Wickham L.D., Mohammed M., Growth, development and quality attributes of miniature Golden apple fruit (Spondias cytherea Sonn). Part I: Fruit growth and development to maturity, Food, Agric. Environ. 2 (2004) 90-94.

[5] Geurts F., Blaak G., El Baradj T., Anacardiaceae - Spondias cytherea (Ambarella), in: Genetic resources of tropical and subtropical fruits and nuts (excluding Musa), Int. Board Plant Genet. Resour., Roma, Italy, 1986, pp. 18-19.

[6] Massiot P., Baron A., Farhasmane L., Parfait A., Evolution of cell-wall polysaccharides of Cythère plum (Spondias cytherea) in the extraction and clarification of juice, Sci. Alim. 11 (1991) 477-489.

[7] Eugène S., Essai d'amélioration de la qualité du nectar de prune de Cythère (Spondias cytherea) par élimination enzymatique de l'amidon, ENSIA-SIARC, Mém., Montpellier, France, 1995, $50 \mathrm{p}$.

[8] Anon., EasyRGB-PC software, version 1.20, Logicol S.r.l., Trieste, Italy, 1996.

[9] Askar A., Treptow H., Analytical methods, in: Askar A., Treptow H. (Eds.), Quality assurance in tropical fruit processing, SpringerVerlag, Berlin, Germany, 1993, pp. 9-10, pp. 19-20, pp. 27-28.

[10] Bietz J.A., Micro-Kjeldahl analysis by an improved automated ammonia determination following manual digestion, Anal. Chem. 46 (1974) 1617-1618.

[11] Doyon G., Gaudreau G., St-Gelais D., Beaulieu Y., Randall C.J., Simultaneous HPLC determination of organic acids, sugars and alcohols, Can. Inst. Sci. Technol. J. 24 (1991) 87-94.
[12] Anon., Starch - UV method for the determination of starch in foodstuffs, in: Methods of enzymatic food analysis, Boehringer Mannheim GmbH Biochemica, Tech. leafl., Mannheim, Germany, 1977.

[13] Robertson J.B., Van Soest P.J., The detergent system of analysis and its application to human foods, in: James W.P.T., Theander O. (Eds.), The analysis of dietary fiber in foods, Marcel Dekker, New York, 1981, pp. 123158.

[14] Anon., Official methods of analysis of the association of official analytical chemists, AOAC, Washington, DC, USA, p. 746.

[15] Singleton V.L., Rossi J., Colorimetry of total phenols with phosphomolybdic-phosphotungstic acid reagents, Am. J. Enol. Viticult. 16 (1965) 144-158.

[16] Daum J.K., Thorsteinson C.T., Determination of chlorophyll pigments in crude and degummed canola oils by HPLC and spectrophotometry, JAOCS 66 (1989) 1124-1128.

[17] Ting S.V., Attaway J.A., Citrus fruits, in: Hulme A.C. (Ed.), The biochemistry of fruits and their products, Vol. 2, Acad. Press Inc., London and New York, 1971, pp. 107-169.

[18] Vinson J.A., Su X., Zubik L., Bose P., Phenol antioxidant quantity and quality in foods, fruits, J. Agric. Food Chem. 49 (2001) 53155321.

[19] Corthout J., Pieters L., Claeys M., Berghe V., Vlietinck A., Antiviral caffeoyl esters from Spondias mombin, Phytochemistry 31 (1992) 1979-1981.

[20] Minguez-Mosquera M.I., Gandul-Rojas B., Garrido-Rojas B., Garrido-Fernandez J., Gallardo-Guerrero L., Pigments present in virgin olive oil, JAOCS 67 (1990) 192-196.

[21] Cano M.P., HPLC separation of chlorophyll and carotenoid pigments of four kiwi fruit cultivars, J. Agric. Food Chem. 39 (1991) 1786-1791.

[22] Sudo T., Igarashi S., Homogeneous liquidliquid extraction method for spectrofluorimetric determination of chlorophyll a, Talanta 43 (1996) 233-237.

[23] Fils B., Buret M., Parfait A., Rapport de fin de travaux sur la prune de Cythère, Inra, PetitBourg, France, 1986, 11 p.

[24] Mangos T.J., Berger R.G., Determination of major chlorophyll degradation pigments, $Z$. Lebensm. Unters. Forsch. A 204 (1997) 345-350. 


\section{Caracterización físico-química de la ciruela de Citera madura verde (Spondias cytherea Sonnerat).}

Resumen - Introducción. La ciruela de Citera verde madura (Spondias cytherea Sonnerat) se utiliza en las Antillas francesas para la preparación de un néctar. Las características morfológicas y la composición de esta fruta se determinaron con el fin de mejorar a largo plazo sus condiciones de transformación para una calidad mejor de la bebida obtenida. Material y métodos. Se recogieron en Martinica (las Antillas francesas) frutas verdes maduras y se caracterizaron: el diámetro, la longitud, el peso y el color; se midieron el $\mathrm{pH}$, la acidez valorable, los sólidos solubles, los azúcares, las proteínas, el almidón, las fibras, la vitamina C, los fenoles y los pigmentos verdes. Resultados y discusión. La longitud, el diámetro y el peso medio de las frutas fueron respectivamente $71 \mathrm{~mm}, 54 \mathrm{~mm}$ y $116,4 \mathrm{~g}$. Con un pH bajo $(2,6)$ y una elevada acidez valorable (1,3 g Eq ácido cítrico $100 \mathrm{~g}^{-1}$ materia fresca), la ciruela de Citera verde es una fruta ácida comparable al limón. El fruto es rico en vitamina C $\left(52,0 \mathrm{mg} \cdot 100 \mathrm{~g}^{-1}\right)$, en fenoles $\left(349,5 \mathrm{mg}\right.$ Eq ácido gálico $\left.100 \mathrm{~g}^{-1}\right)$ y en almidón $\left(7,1 \mathrm{~g} \cdot 100 \mathrm{~g}^{-1}\right)$. El color verde pálido de la pulpa industrial se debe a los feofitinas a y b. Conclusión. Nuestro estudio proporcionó un análisis detallado de ciruelas de Citera verdes maduras que se tendrá en cuenta para mejorar las condiciones de su transformación en néctar.

Francia / Guadalupe / Spondias cytberea / Anacardiáceas / frutas / composición quimica / ácido ascórbico / almidón / fenol / clorofilas / feofitinas

To access this journal online: www.edpsciences.org 